\title{
THE INDIAN OCEAN AS A UNIFYING FORCE: A MEMOIR
}

\author{
Lindsey Collen
}

I write this during the lockdown that has stopped a good deal of the world's ordinary activities. Whole countries have had to bring their national economies to near standstills just to daunt the New Coronavirus epidemic. Yes, it has taken something as small as a virus to make us see, even if momentarily, our destinies as one. Humanity as one. Humanity must be one. And yet it is a tall order. As US President Trump reminds us when he announces that China must "pay" for the virus. That sounds more like a threat of war. As always, things pull in different directions at the same time.

Anyway.

It is a good time to mull over the Indian Ocean, which surrounds us in the Republic of Mauritius, and on whose shores I was born -though far away from here- and around whose shores I have lived most of my life. For me, the Indian Ocean has been a unifying factor, not a border. But, things that stare you in the face are not always easy to see. And right now, as if to highlight the contradiction, what with the Indian Prime Minister Narendra Modi going as nationalist as Trump, and both India and Pakistan having nuclear bombs, the Indian Ocean does not seem a unifying force for anything more than a few individual lives, mine just one.

I was born -fate had it- within days of the apartheid regime being voted in by the white minority electorate in South Africa. It feels like a curse.

It was 1948.

I was born in the village of Mqanduli, some 15 miles from the Indian Ocean on a dirt road that meandered through the most beautiful hills in the world, where each family lived in a perfectly round hut with thatch so beautifully laid that it reflected sunlight, a small herd of cattle in the kraal, some chickens, and a plot of mielies and pumpkins. Women wore ochre robes and turbans and old ladies smoked long pipes. Young men were off, working in the mines on the Rand and fruit-picking in the Cape. Children walked long distances in their uniforms to mission schools. Pre-apartheid South Africa was already segregated by the previous Jan Smuts regime, though not yet "classified". So, the village of Mqanduli was white -traders, civil servants, a doctor and a labour recruiting agency- and a few coloured families. Smuts, en passant, was notable for sitting on Churchill's war cabinet and for having been named from 1940 as Churchill's replacement as British Prime Minister, if need should arise. Think of that. 
Anyway.

The first two decades of my life were spent living in different parts of South Africa -mostly inland: from Mqanduli to the capital Pretoria then to the hamlet Bochum way up North from when I was two to five years old and where I became trilingual, being the only person to speak any two languages in the little compound we lived in, so became a constant formal interpreter from English to and from Sotho, Sotho to and from Afrikaans, and English to and from Afrikaans -hence my life-long love of mother tongues. Then we moved to the village of Xalanga where I learnt Xhosa, and where at 6 years old I published my first two articles and self-published and even self-printed a book of poems, then to the capital of Natal, Pietermaritzburg where I saw young Indian girls my age with gorgeous, brightly coloured bracelets and clothes with glitter sewn in, and where I played dressing up in smart people's unclaimed fur coats at my friends' father's dry-cleaning shop (he had come to Pietermaritzburg as a Jewish refugee from Nazi Germany, as had his wife). Then it was back to rural Eastern Cape to Qumbu. And then to East London to a government boarding school, Clarendon, for girls who were, by then, classified as being "white", where I participated in rebellions against the school authorities and apartheid. For five years I lived in East London, an Indian Ocean port city that was always being silted up, and even if we were kept "in" because it was not unlike a prison, I was constantly aware of the smell of the Indian Ocean as the trade winds hit us. Finally my family was moved to the Highveld city-of-all-cities, Johannesburg, the centre of the gold mines, where my father was put in charge of an Alexandra Township in rebellion, and during which time I was at the University of the Witwatersrand and for the first time was involved in conscious struggles, as opposed to rebellions.

But, every year, from the time of my birth, for a full month, I spent five weeks out of 52 looking over the Indian Ocean.

It was from a place on the Mbashe River Mouth in the Eastern Cape.

There, I literally looked at all that sea. I looked out from a run-down holiday resort we went to every year. It was part of my parents' marriage contract -my mother had to follow my father around, he being a magistrate/native affairs commissioner/ Bantu affairs commissioner- and so to give her a sense of continuity, they spent five weeks every year, my father's entire leave, at this tranquil place, lost to the modern world. It was where my mother had spent her holidays every year from when she was a baby, too, being very near Mqanduli where she grew up. This was my stable experience of the Indian Ocean for 18 years.

This bit of the Eastern Cape, like Mqanduli nearby, like two other places I lived for years, Xalanga and Qumbu, was what was "the fault line" on the geography of South Africa. It was left like a gash on the earth's skin after the colonial subjugation of the peoples of Southern Africa. It was a fault line that you could feel, if you cared to.

The British troops, after eight different wars of conquest against the Xhosa peoples for 100 years from 1779 to1879, left a bit of land in the Eastern Cape as a "native reserve", later notorious as a Bantustan: the Transkei. This part of South Africa was really only subjugated from 1856 onwards after the mass movement to kill cattle and burn crops -in a desperate attempt to get rid of the invaders - after 
which resistance seemed broken. But it was not. The fight was still there. I could feel it as I grew up.

So, it was on this truce line that my father was born, my mother was born, I was born, and that I lived much of my childhood life on, and that we, as a family, in addition always spent five weeks a year on.

For that annual holiday, we were on a grass koppie on the edge of a thick forest that I grew to know like the back of my hand, trained by my mother who knew it before me. And we looked out over the Indian Ocean. And as I looked out at the Indian Ocean, on my left was a lighthouse warning ships of the dangerous rocks and currents. The rundown hotel we stayed in was constructed with the flotsam from shipwrecks over the decades. Even a dog swam ashore from one. On the right, out of sight was the huge Mbashe River pounding into the sea, bringing red mud, and attracting rough farmers from the Vaal River area with their fishing gear for the cob fishing in season. The mail ship went past at night, all lit up, once a week, carrying letters and parcels. The rest were endless merchant ships. All this movement on the ocean. And we watched the dolphins that we called porpoises following the sardines. Maybe they were porpoises.

The fault line, or truce line, in South Africa's history means that many of those born on it have the gift of seeing both sides at once. We have the gift of more than one pair of eyes: Nelson Mandela comes from Mvezo, here; Neville Alexander from not far away-Cradock; Chris Hani, too-Cofimvaba. These are the famous ones. Anyway, maybe it gives those of us interested in such things not just the ability to see more around us than our own family circle, but to, perhaps more easily, get the desire, even a burning desire, to see the whole, big picture. Living on a fault line, we can easily see different classes of people impinging on reality in different ways, and being impinged upon differently. We hear the memories of the colonizers' invasion and the pushback of the colonized as they tell it to us, themselves. In endless stories. Even more than that: the fault line shows how things were before things were like they are now and even gives a hint as to how things were before then. And also perhaps to envision how things can perhaps be afterwards, what they might be like. If we have the flair for imagining waves of past history, why not hazard taking a look at the swells into the future? Such is the destiny of those born on a fault-line: it is a presence you can feel, if you care to.

And so, we, those born on this particular fault line, are always reminded that there were people thousands and thousands of years before us, people who had lived on this land, lived there before those of us who shared our lives with our herds of beloved cattle, without those of us who planted our sorghum or maize, long before the colonizers came with their trade, their one god and their machines. We feel them: They were the hunters and gatherers, those humans who understood the earth better than we do. From whom we may now need to learn. They understood it so well that they could sustain human society for maybe 200000 years in that exact part of the world, while we the planters, the millers and bakers, can't seem to manage 10000 years without so many break-downs in transmission. And as for humans in the time of the industrialists and the bankers, in the 300 years since they came to power, we are already wrecking the joint. They, the wise people who 
hunted and gathered before us, were our forefathers, our foremothers. They roamed the mountains and hills, and stared over the Indian Ocean. They knew that the purpose of life was to visit people and listen to their stories. And they left art-work on the walls of caves to remind us of this. And they made musical instruments from the fencing wire with which the colonizers fenced them out of their immense lands. This is the human past, the collective human heritage that we, who lived on that fault-line, don't just have, but that we know we have, or more precisely that we can know we have. Meaning we are all one. Whatever you might see on the surface. We didn't have to wait for the Coronavirus to remind us.

Anyway, the resort we stayed at was kept going for the first 11 years of my life, as I say, by the flotsam, and maybe some jetsam before the actual moment of the wreck, washed ashore from the ship called something like Koondoochee-it was perhaps an India-based ship. Towels and sheets, even pillow cases, had the ship's insignia embroidered into the corners. Furniture -beds and chairs and tables, even benches- all had the name of this ship branded into the planks they were made from. The next 11 years or so, the resort was kept alive by flotsam from another shipwreck: the Laerca, or something like that, a Russian ship. This was the ship whose dog swam ashore out of the Indian Ocean, shook himself on the beach, and was called forever by the name of that sunken ship, Laerca. And, just as the previous stock of towels were wearing thin and no longer absorbing water, new ones washed ashore. Just as the furniture made out of the first ship was becoming more and more disreputable, and good for nothing but to fling into the coal burner, there came a cargo of floating raw materials for the resident carpenter. The original owner of the place was, in fact, a ship's carpenter from Aberdeen given a lease and permit after the Great War -as it was called. And my maternal grandparents were friends of his. Also from Aberdeen.

A word on why we wandered around this way, our own nuclear family, all over South Africa: My father, though against apartheid, was an implement for setting it up and enforcing it. He was the state. And he was transferred to wherever his colleague pro-Nationalist, pro-apartheid Commissioners did not want to go. Usually because it had become the most dangerous place for such a civil servant to be in. My mother detested the apartheid system and was not, by law, allowed, while married to a civil servant, to be involved in politics. So, my political engagement, I put this in brackets, is, in a way, nothing more than my living a life my parents would have, themselves, lived had they, at some point, taken a drastic decision. Which they did not. They, too, were born on the fault-line, so had a certain wisdom. I merely did in my political life what they might have done.

So, anyway, the Indian Ocean was what was stable for me. For five weeks a year. Its waters, its crashing breakers, its swells, and its lagoons, its gullies, its fish, its dolphins, its ships, its estuaries and river mouths, like the Mbashe and the Mbanyana, and higher up their waterfalls, its Cwebe forest, thick and with 30-foot tall trees, with green mambas and other dangerous snakes, brightly coloured birds, and botanical rarities that were still being catalogued at the time I was a child. I acted as the forest guide to a botanist doing the collecting of species of plant for the University of Natal as it was then called. 
This resort's rickety dining room chairs and out-of-tune piano relied on guests for upkeep. And if amongst guests there was not a plumber of sorts to repair the septic tanks out back, the toilets, too, would not have worked. One such plumberguest had written a sign in the men's loos, my brothers told me when they had just learnt to read and didn't get the joke yet, "Do not throw stompies into this septic tank. They get soggy and hard to light." Cheapskates, my brothers said, those must be.

And I meanwhile watched the strange society exposed on the truce line, the fault line scarring the land. But I watched from the edges of the society.

The bedrooms of this ramshackle hotel were separate rondavels for each family. And these were just like the staff quarters' rondavels higher up on the hill behind the resort, where the workers and their families lived.

So, we had this apartheid -never more than a few metres apart- of white holiday-makers with four or five senior staff of the resort living in one society alongside the black African workers, staff of the resort. Living not apart, but as one entity: a sort-of hotel.

And my mother and father and I as a child spoke Xhosa, so we saw both worlds, by not just hearing both, but by listening to them.

And I would look out over the Indian Ocean for hours - as ships plied the dangerous waters out front- trying to make sense of the rest of the country and the rest of the world.

And wherever I went in South Africa, from all those such different perspectives that I was privileged to be given by my father's incessant transfers, including this fault line perspective again and again and again, I still could not understand what was going on in the country, let alone in the rest of the world. I had the desire to. But I couldn't understand a thing.

It was to me a confused mass of contradictions. And I never stopped thinking about it.

What was the country? First, the Union of South Africa? Then from 1961, the Republic of South Africa? What was the world beyond? You could learn the technicalities as taught in schools. And then again, my parents were informed and well-read people. There were even encyclopaedias. I was also, of course, treated to anecdotes by my grandparents about their parents. And I listened to endless stories from wise women, in charge of looking after me, about the past and about things you can't see but that exist.

But, as a whole, it all made no sense.

Where did the people like my family come from, to be here? And why? I knew what I was told: my paternal grandad came from a London Baker's family and my granny, a Scots sheep farmer's daughter, out to Umtata to set up Collen's bakery in what was a Native Reserve. My granny, if arguments arose, threatened my grandad with a repeat of the Battle of Bannockburn. My maternal grandparents came from Aberdeen to work as itinerant book-keepers, given permits by the Authorities of the new Union of South Africa to audit the books of all the retail shopkeepers in that part of the Eastern Cape who traded with African farmers. But, in what interests was all this conquest that so clearly had gone on? The wars? Clear land-grabs? My maternal grandad had stopped speaking to any of the other white people in Mqanduli from 
a political feud that took place before I was born, when the village council ousted the Coloured people from their land. That was before apartheid. And what was this enslavement, this working in the diamond mines then the gold then the coal mines? Enslavement of my maternal uncle and of all the young Xhosa men who worked underground. My uncle spoke Xhosa as a native speaker. I only ever had one hint: my grandad, this one, informed me that I should never trust the ruling class -I had no idea what he meant- especially your own, in his case the Scots ruling class. But, it did not get me far.

I never met any explanation -not in Mqanduli, not even in Pretoria, the capital, nor in Bochum up North, nor in Xalanga, nor in Pietermaritzburg in Natal, nor in Qumbu, nor in East London, looking out over the Indian Ocean from the windiest of all cities. All those places, each with a perspective, and still I couldn't understand a thing.

It was only when I came to Johannesburg, far from the sea, up in the Highveld, that I finally began to see the light of day. And it was accidental.

I enrolled at the University of the Witwatersrand, and when on my way to the campus on my very first day, I got lost walking down from the bus stop, I fell in with youngsters who were the children of the bourgeoisie. Only then did I begin to understand.

There had been a social class missing in all the people I had ever met or ever even seen in my whole life. And what I read failed to unmask them, as a class, for me.

So, this class was not only out of sight. It was out of mind.

But at Wits, I saw the class. So I got to know it was there. And to keep it in mind.

The parents of the kids, who became, by this strange coincidence, my circle of friends, owned huge construction firms, owned real estate companies, owned and ran gold mines, owned immense international commercial enterprises, ran shipping companies, represented huge European firms in South Africa, ran the stock exchange, and so on. The more lowly amongst them were the country's top lawyers, who served them. These friends thought I was the country bumpkin that wore strange clothes, had a cheek and was argumentative. We organized big demonstrations of thousands of students against the final, last imposition of total apartheid in our University.

I also, of course, had access to books.

Although at the time, during apartheid, you had to have a special permit to read Marx and Engels and any other communists, who may have told you of the existence of a class called the capitalist class.

And I also became friends with a young American student whose father was a finance capitalist who, having fallen foul of the Federal Internal Revenue Service, arrived penniless in Johannesburg where he was free from the threat of extradition. He had not a cent on him. His son was at University with us, and told us how penniless they were. Six months later he invited me to his parents' house. His father by then owned a massive estate north of Johannesburg, with a lodge (for some part of the servant class, at the gate to the estate), a lodge twice as big as our family's house in Highlands North, and a garden the size and scope of Pamplemousses Garden in Mauritius. Then I began to see how things work. The friend explained it to me. $\mathrm{He}$ 
had worked as an assistant to his father before his flight from the tax-men. So, then I saw the class of finance capitalists, too, who know which new billion-dollar project suddenly needs funds and which funds somewhere in the world are suddenly freed up for investment at the same time. His father was one of those. He was trusted. It's all there to see. You only have to look.

So, I saw across the seas, across the oceans including the Indian Ocean, from inland. To the financial centres like London and New York. To the colonial pillage and conquest. To the industrial centres like Manchester and Liverpool. And how my grandparents' long sea voyages all the way out to the Cape Colony, were, in fact, dictated, as part of mass displacement, by the economic dynamics controlled from these centres. The economic dynamics ran slavery, waged war, set up frontiers, taxed people, recruited them to sell their labour power, and passed laws to order them. The lot.

And this was all run from the heart of the capitalist hub out to the spokes in the rest of the world -upon one of which I was amongst those millions impaled. Well-nigh unable to get a view of things.

When I landed in Johannesburg in 1965, even before I went to Wits, all I could see as I was walked or went on motorbikes or caught buses around the city were these huge mine dumps. No-one had warned me. Huge big barren geometricshaped mountains in the middle of a huge city. This one pale orange, that pale pink. This one beige, the other one pale mauve. The mines under the ground. A mile under the ground, some of them. Into the real heart of darkness, into which working people were press-ganged. While the banks above them in the bright sun ran the mines, and then the merchant banks ran the banks. And the banks and merchant banks, with their mine-owners and factory owners, and the big farmers, got to run the Government that ran the country, including my father. All with a lot of push-and-pull between different interests.

And so everything, the broad outline, fell into place.

All the rest of society, however high up, just works for this class, one way or another. The higher up work at getting all the rest of us to keep working for that top-dog class, and to work as quietly as possible for them, for them to rake in money so big it increases the size of their capital. No questions asked. I had not been supposed to be asking big questions. But being born on a fault-line, you might have a tendency, like I did, to do so. And then, all the different perspectives from which I had seen South Africa and the Indian Ocean, in turn, helped.

Whether in colonial pillage pre-apartheid days, or during apartheid or even today, when we hear the sound of the shots fired at the striking Marikana platinum miners even before the shots from Sharpeville or Soweto have stopped ringing in our ears, and when there is still the echo in our collective memories of Jan Smuts actually bombing from the air, people striking against a dog tax and hut taxes in 1917 in Namibia -it becomes clear who and what the driving forces are. All these excesses of the State, and the very State itself, work ceaselessly in the interests of this small, powerful class that most people cannot even see.

Before going to Wits, I had never seen higher than a preacher, a magistrate, a retailer, a dry cleaning workshop owner, a baker, a cloth seller, a doctor, a farmer 
-and a vast mass of workers, so-called intellectual workers like teachers, lecturers, clerks, and nurses and so-called manual workers, from carpenters and electricians to railway workers, mine-workers, and field labourers, rubbish collectors cleaning up after us and minters making the coins, as well as peasants, eking out a living from the land. And I had "seen" millions of people, what with all these different viewpoints I had the privilege to stand on during my life in South Africa.

So it is in Mauritius today.

In the middle of the Indian Ocean, where I have lived for over 45 years, I still never really meet anyone from that class of owners of sugar estates, banks, off-shore companies, tourist hotels or real estate magnates but I do now have the advantage that, from my days at Wits University, I learnt that they are there. And they are the ruling class. They still rule. They still divide and rule.

So, I see the bourgeoisie. I see the interests the colonial powers had in Africa and India and, on the way between them, Mauritius. I understand the phrases in the history books about "The Dutch East India Company" that seemed to me to be the Government, and then "The British East India Company", ditto that mystified me for 20 years of my life. How come a company is a Government? And I could see the ruling colonial classes world-wide, too, in retrospect, as they quickly de-colonized around us from the time of my birth in the 1940s, quitting India, while apartheid took the hard-line colonial path, and both went on -the decolonizing and the hard line colonizing- through to the 1960s and 1970's when the colonizers finally got out of Mozambique -until 1994, when South Africans finally defeated apartheid. Now there remains Palestine, at the top end of the Indian Ocean, colonized today by the US-Israel alliance. And Diego Garcia, part of Chagos, part of Mauritius, bang in the middle of the Indian Ocean, with a US military base on it. Both now declared illegal by the highest International Court. But still colonized, anyway. Two struggles I'm still involved in.

In between then, South Africa and Mauritius, where did I live and what did I learn, and are there other links to the Indian Ocean?

For a year, I lived in the United States, on a farm in upstate New York in the beautiful Chautauqua County on the foothills of Appalachia. I lived and went to school amongst the rural poor who are often "invisible" in the US. And today over 50 years later, I listen, during the lockdown, to New York State's Governor Andrew Cuomo's famous daily Coronavirus briefing as he refers to all the parts of NY State I knew, just after listening to the Mauritian Coronavirus briefing. A strange juxtaposition.

I visited the New York City Stock Exchange from which the world's finances were and still are run as well as Fort Knox where the gold dug out of the ground in South Africa ended up in ingots. Today Fort Knox still stores 4,583 tons of gold underground for the Federal Reserves. How many mine dumps sticking into the air in Johannesburg does that represent? How many workers' toiling in the dark passages underground brought that stock there?

So, knowing something of the contradictions of American society-from its beautiful jazz clubs to its working class pubs, from its parochialism, which can mean people don't notice the Indian Ocean exists and might believe Africa is a country, 
to the country's persistent slave-mentality hangover so frighteningly present, from its lively debates to its hysteria against communism, from its anti-Vietnam war movement at the time to its hypocritical conservatism -has helped me understand its present decline as a super-power and as an empire and the reactionary storm this is creating.

Other viewpoints were eclectic.

Like, I later lived for a year in the Seychelles, plumb in the middle of the Indian Ocean. I sailed there from Durban in a ship called the Karanja which meandered up the Indian Ocean's western shores into Maputo still called Lorenzo Marques, into Beira, Mombasa, Dar-es-Salaam and then on to Mahe. I felt the Indian Ocean -its size, the similarities of the port cities on its edges, its age. And on that trip, in the middle of the doldrums, we came across an ancient calmed dhow and our ship gave them water to fill all their containers and I saw how long it had been that there had been links across the whole of the Indian Ocean, just looking at that enormous boom on that enormous handmade sail ship; and colonization suddenly seemed a recent phenomenon.

And it was when I was in the British colony of the Seychelles that three of its islands were being stolen by the British and put after Chagos into the invented colony "British Indian Ocean Territory" so that the USA could later set up its base on Diego Garcia. And later, it would be my brother-in-law (my husband's sister's husband) who would advise the Seychelles Government in a case to win the Islands back, which they did. And then Ram and I would be involved in struggling to get the rest of Chagos re-integrated with Mauritius and to get the base closed down.

And I also lived a year in London, where I worked as an illegal worker in various jobs like a sandwich bar on Carnaby Street, then as a temporary typist at Johnson Matthew Metals Merchant Bank in the City of London which further educated me on finance capital, and then at the multinational Rank Xerox. I studied at the LSE and it was in London that I met my partner, Ram Seegobin, who is Mauritian. Amongst other things, we gave a hand with a support group for the liberation of Mozambique, Angola and Guinea Bissau from Portuguese colonization. And this is how we ended up going to Tanzania, where we ended up living a few months looking out at the Indian Ocean together.

We went to Dar-es-Salaam in order to complete our signing up to work in the liberated zones of still-colonized Mozambique -as doctor and teacher respectively. But political history was moving apace. Just then, there was the coup in Portugal that got rid of the Portuguese dictatorship and overnight Frelimo that ran the liberated zones, moved its headquarters from Dar-es-Salaam to Europe. And we would have had to return to London to sign up. And in any case, it would not be the same to work for a predictably bureaucratic regime that Frelimo could be expected to become. So, we stayed in Tanzania for three months. There right on the sea front just north of Dar-es-Salaam, we looked out over the Indian Ocean every day. Ram taught friends there to dive in the sea, since he recognized it as so similar to what he had known under the sea in Mauritius; and then -since we were so nearby- we decided to catch a plane over and visit Ram's parents in Mauritius before going home to London. 
And Mauritius, coming out of the post-Independence state of emergency, was so interesting, socially speaking, that we stayed, moved into a house in a village, and got involved in grassroots struggles and left-wing politics. Right here in the Indian Ocean.

And, talking of the ocean, we bought an old fishermen's pirogue and began fishing in the traditional ways off the west coast of Mauritius. I learnt the ways of dolphins and whales and birds and turtles and fish, and the currents, the winds, the different kinds of rains, and how to smell a cyclone's approach. And so it was that I learnt the ways of traditional fishermen, as we became of them.

And later when there was a bit of doldrums in the struggle of the working class that had had its heroic days in 1979 and 1980, shaking the bourgeoisie rigid, when I found I had a bit of spare time, that was when I began to write the novels I had always been threatening in jest to write. "Can I put that in a novel I intend to write?" I would joke with people. I never thought I would. But I did. Seven. All set in the Indian Ocean.

And the novels were set mainly in the social reality I live in, in Mauritius among the rural working class. Surrounded as I am by people who had moved or been moved by force from Africa, Madagascar, India and a handful from France, across the Indian Ocean wherever they started from, and who have created a language that I love, Mauritian Kreol, and a society that I love, and that is today under threat of new forms of colonization even before the old are over: While Diego Garcia (and the whole of Chagos) are still illegally occupied, although Lalit the party I'm in has finally forced, after 40 years' struggle, the Mauritian State to go to the UN Court, the ICJ, where last year Britain was declared an illegal occupier -and while the Mauritian Kreol language is still banned as the written form as medium for children to learn maths and science, and is still banned in Parliament, there is now a new kind of re-colonization beginning. It is along the lines of the Israeli-plus-US colonization of Palestine: the buying of the arable land, and in the Mauritian case, selling it off to millionaires from all over the world and giving them citizenship to boot. And while the State subsidizes the sugar estate owners as they sell off their "real estate" (the arable land) and also thus subsidizes the millionaire new settlers, this same State has not been able even to replace the asbestos housing that is a colonial legacy in the working class, nor to assure a modicum of food security during and after the Covid-19 pandemic. And, through WTO agreements, today the Mauritian State hounds out traditional fishermen from the sea, as Hilton Hotels and others take over the lagoons and as international fishing companies (Spanish, French, Korean, etc.) fish the massive territorial waters of Mauritius.

Mauritius, as you know, is the 18th or 19th biggest country in the world -counting, land and water. I say that because I'm sick of people saying it's small, as if small is an excuse for all manner of things.

So, it is not "a small island". It is part, rather, like any other, of our beautiful, little planet. A planet threatened. 2006.

And before signing off, one last Indian Ocean eye-opener I had. It was in 
There was a "Conclave of Writers" held at a beautiful old palace called Neemrana. Fifty of us writers from Africa and Asia were brought together to look at where the world was 50 years after the Bandung Decolonization Conference. Congress was back in power after ousting the first BJP stint in power, and the conclave was perhaps a way of recentring the Congress role in decolonization. But, for writers it was a rich, multi-viewpointed image, a kaleidoscope of all angles on the Indian Ocean. And getting such a view from African and Asian writers was both vivid and unforgettable.

At the same time, staying at Neemrana gave me a second viewpoint on India: from right near the top in a palace. I had only seen India from the very bottom before, when, by mistake, I booked six of us into a hotel that was both a brothel and in a shit canal and situated in a squatters area, when we were attending a No Bases Conference in Mumbai two years earlier. So, again, by chance I was reminded of class society, living later in one of the most beautiful old fortresses of India.

And, as I write, I think how we live in times when the capitalist class worldwide is led by two warring factions -the globalists who want capitalist investment in every nook and cranny and then, worse still, the nationalists, led by Trump and various fascistic groups elsewhere, who remind us every day of how fascism rose in the 1930s.

At least seeing this is a beginning.

And then there are the rest of us. And it is up to us to halt this rise in fascism. And it is up to us to go further than that and to change society so we all decide together how to proceed, not just a handful of us.

And now the Coronavirus has come to remind us, all the rest of us, that our destinies are one.

If we do not act as one humanity, we are in trouble relative to something as tiny as a virus. Let alone the trouble we face from other calamities. There is the pollution caused by our ruining classes that is bringing us to the verge of any number of tipping points -worldwide- while there are nuclear weapons constituting a constant threat, what with reckless men's grubby fingers on nuclear buttons. And this is true on the shores of the Indian Ocean, too, as well as elsewhere -with two nation states-India and Pakistan -having the power to destroy all of this one humanity, as well as the others like USA, Russia, UK, Israel, France, China and North Korea.

We do need, right now in history, to be reminded by the hunters and gatherers of old how to sustain society, how to be one. Only when we are one humanity can we hope to save the planet. For the past few centuries that would have sounded like an exaggeration. Right now it's an understatement.

But one that our ancestors for the first $95 \%$ of our common human history, as they looked over the Indian Ocean from the escarpment, would have understood. 
